\title{
The genus Bilharziella vs. other bird schistosomes in snail hosts from one of the major recreational lakes in Poland
}

\author{
Anna Stanicka ${ }^{1, *}$, Łukasz Migdalski ${ }^{1}$, Kamila Stefania Zając ${ }^{2}$, Anna Cichy ${ }^{1}$, \\ Dorota Lachowska-Cierlik ${ }^{3}$ and Elżbieta Żbikowska ${ }^{1}$ \\ ${ }^{1}$ Faculty of Biological and Veterinary Sciences, Department of Invertebrate Zoology and Parasitology, Nicolaus Copernicus University in \\ Torun, Lwowska 1, 87-100 Torun, Poland \\ ${ }^{2}$ Institute of Environmental Sciences, Jagiellonian University, Gronostajowa 7, 30-387 Krakow, Poland \\ ${ }^{3}$ Institute of Zoology and Biomedical Research, Jagiellonian University, Gronostajowa 9, 30-387 Krakow, Poland
}

Received: 3 November 2020 / Accepted: 4 March 2021

\begin{abstract}
Bird schistosomes are commonly established as the causative agent of swimmer's itch - a hypersensitive skin reaction to the penetration of their infective larvae. The aim of the present study was to investigate the prevalence of the genus Bilharziella in comparison to other bird schistosome species from Lake Drawsko - one of the largest recreational lakes in Poland, struggling with the huge problem of swimmer's itch. In total, 317 specimens of pulmonate snails were collected and examined. The overall digenean infection was 35.33\%. The highest bird schistosome prevalence was observed for Bilharziella $\mathrm{sp}$. $(4.63 \%)$ in Planorbarius corneus, followed by Trichobilharzia szidati $(3.23 \%)$ in Lymnaea stagnalis and Trichobilharzia sp. (1.3\%) in Stagnicola palustris. The location of Bilharziella sp. on the presented phylogeny showed that it is with high probability a different species than known so far B. polonica. Our finding complements the confirmed occurrence of bird schistosomes in European water bodies. Overall, presented research reveals the special importance of $P$. corneus as a source of the bird schistosome cercariae. This study suggests that the health threat connected with the blood flukes need to be further investigated by constant monitoring of their occurrence in intermediate hosts.
\end{abstract}

Keywords: Bilharziella sp / Trichobilharzia spp / swimmer's itch / Planorbarius corneus / Lymnaeidae

\begin{abstract}
Résumé - Le genre Bilharziella vs. d'autres schistosomes d'oiseaux chez les escargots hôtes dans l'un des principaux lacs de loisirs en Pologne. Les schistosomes d'oiseaux sont communément admis comme étant l'agent causal de la démangeaison des nageurs - une réaction cutanée hypersensible à la pénétration de leurs larves infectieuses. L'objectif de la présente étude était d'examiner la prévalence du genre Bilharziella par rapport aux autres espèces de schistosomes d'oiseaux du lac Drawsko - l'un des plus grands lacs de loisirs de Pologne, aux prises avec l'énorme problème de la " puce des canards ». Au total, 317 spécimens d'escargots pulmonés ont été collectés et examinés. L'infection globale était de 35,33\%. La prévalence la plus élevée de schistosomes d'oiseaux a été observée pour Bilharziella sp. (4,63\%) chez Planorbarius corneus, suivie de Trichobilharzia szidati $(3,23 \%)$ chez Lymnaea stagnalis et de Trichobilharzia sp. (1,3\%) chez Stagnicola palustris. La position de Bilharziella sp. sur la phylogénie présentée a montré qu'il s'agit très probablement d'une espèce différente de celle connue jusqu'à présent comme B. polonica. Notre découverte complète la présence confirmée de schistosomes d'oiseaux dans les masses d'eau européennes. Dans l'ensemble, les recherches présentées révèlent l'importance particulière de $P$. corneus en tant que source de cercaire de schistosome aviaire. Cette étude suggère que la menace sanitaire liée aux schistosomes doit être étudiée plus en profondeur par une surveillance constante de leur présence chez les hôtes intermédiaires.
\end{abstract}

Mots clés : Bilharziella sp / Trichobilharzia spp / puce des canards / Planorbarius corneus / Lymnaeidae

\footnotetext{
*Corresponding author: anna.marszewska@umk.pl
} 


\section{Introduction}

Bird schistosomes (Trematoda: Schistosomatidae) are parasites with a complex life cycle. The first intermediate hosts are mainly the pulmonate snail families Lymnaeidae, Planorbidae and Physidae (Horák et al., 2015), whereas the final hosts include birds as Anatidae, Ardeidae, Ciconiidae and Podicipedidae (Sulgostowska and Czaplińska, 1987). Snails infected with schistosomatid trematodes produce large numbers of infectious cercariae. Thus, even with a low prevalence of the parasites in host species populations, there is a real threat to subsequent hosts in the parasite's life cycle (Marszewska et al., 2016; Soldánová et al., 2016). Infectious larvae are released from intermediate hosts and seek their final vertebrate hosts using chemoreceptors. The similarity between some lipid components in the integument of birds and humans leads cercariae to attack people working, wading or swimming in water (Horák et al., 2015).

Cercariae of bird schistosomes are considered as the causative agent of cercarial dermatitis (swimmer's itch) (Horák et al., 2015) - a persistent itchy rash of aquatic origin, massively occurring during the summer recreation season (Marszewska et al., 2016). In extreme cases, this zoonotic parasitic disease may be accompanied by anaphylactic shock or disorders of the respiratory system (Bayssade-Dufour et al., 2001). Some species of bird schistosomes, those belonging to the genus Trichobilharzia Skrjabin \& Zakharow, 1920, overcame the barrier of the skin of a mammal and reached the internal organs during the experimental study (Horák and Kolářová, 2001). In a mousemodel test a deposition of schistosomula in animal lungs (Olivier 1953, Haas and Pietsch 1991, Horák and Kolářová 2000), liver, kidneys, heart, and intestines was reported (Haas and Pietsch 1991). Moreover, in other mammalian hosts, like hamsters, guinea pigs, rabbits and rhesus monkeys, schistosomula were recorded in their lungs (Olivier 1953). The so-called 'nasal' schistosomes, such as $T$. regenti Horák, Kolářová \& Dvořák, 1998 specimens, are considered to be the most dangerous species by their presence in the central nervous system (CNS), which was also noted in the mice-model test (Horák et al., 2015).

Relatively little is known about bird schistosomes belonging to the genus Bilharziella (Kowalewski, 1895) (Trematoda: Schistosomatidae) (Prüter et al., 2017). Only one species belonging to this genus has been described so far (Horák et al., 2015). It is still under discussion whether $B$. polonica is the causative agent of cercarial dermatitis. Żbikowska (2002) carried out tests on human volunteers under laboratory conditions and demonstrated that Trichobilharzia sp. was capable of causing the symptoms of swimmer's itch, while B. polonica did not cause symptoms of this dermatitis. On the other hand, Szidat (1930) described cases of cercarial dermatitis from Germany probably caused by B. polonica. Moreover, Horák and Kolářová (2000) observed penetration of some cercariae of this species into the skin of unusual mammalian hosts (mice). Some larvae died in the skin (Horák and Kolářová, 2001), but other schistosomula were able to survive and migrate to the lungs in the mice-model test (Horák and Kolářová, 2000). However, recent research indicates that $B$. polonica is not only capable of infecting visceral organs but also the CNS of mallards (Prüter et al., 2017). The parasite species has been found not only in the intestine but also in the spinal cord and between the brain membranes (meninges) and the brain. Prüter et al. (2017) suggest that the comparably high prevalence of B. polonica in the CNS of mallards indicates that the CNS is a target tissue rather than an ectopic localization within the definitive host. The study showed that B. polonica has a broader spectrum of target organs in the final host than previously described.

In particular, research on the occurrence of the genus Bilharziella in populations of potentially important intermediate host species is necessary. The goal of our research was to gain knowledge about the prevalence of bird schistosomes with particular emphasis on species belonging to the genus Bilharziella, in host snails from Lake Drawsko in Poland a place where outbreaks of swimmer's itch have been noted for several recent years (Cichy et al. unpublished data).

\section{Materials and methods}

\subsection{Research area and sampling}

The investigated water reservoir - one of the largest lakes in Poland, is located in the West Pomerania Voivodeship (Fig. 1). The lake has an area of 1781.5 ha (max-length $10.6 \mathrm{~km}$, max-width $-6.6 \mathrm{~km}$ ) and belongs to the category of deep lakes, with a maximum depth of $79.7 \mathrm{~m}$ (Choiński, 1991). Lake Drawsko is inhabited by several species of waterfowl, including members of the Anatidae, which are a potential source of bird schistosome eggs.

Snails belonging to the families Planorbidae and Lymnaeidae were sampled manually using a small metal sieve on a telescopic handle from the bottom, stones, macrophytes, sunken wood and bridges along the accessible lake shoreline to a depth of about $1.5 \mathrm{~m}$, with a focus on the sandy beach where people are mainly engaged in recreation. The snails were gathered by two scientists over three consecutive days, between 8 a.m. to 6 p.m. The samples were collected during sunny and windless days in August 2019 - i.e., during the period of the highest prevalence of bird schistosomes (Marszewska et al., 2018).

\subsection{Parasitological examination of snails}

A taxonomic key (Piechocki and Wawrzyniak-Wydrowska, 2016) was used for morphological identification of snails. Gastropods were placed individually in beakers with dechlorinated tap water and exposed to artificial light for several hours to stimulate the emergence of cercariae. Next, an autopsy of snail gonads and hepatopancreas was conducted. Morphological identification of parasites was performed according to available keys (Cichy and Żbikowska, 2016; Faltýnková, 2007, 2008) using a light microscope (Primostar Carl Zeiss) with various magnification $(5 \times, 10 \times, 40 \times$ and $100 \times)$. Images were recorded using a digital camera (Axiocam 105 color, Carl Zeiss) and a computer system running Zen software (version 2.3, blue edition). Several dozen larvae of bird schistosome (from each snail individually) were isolated from water or snail organs, then fixed in ethanol $(96 \%)$ and frozen $\left(-20^{\circ} \mathrm{C}\right)$ for later molecular identification. 


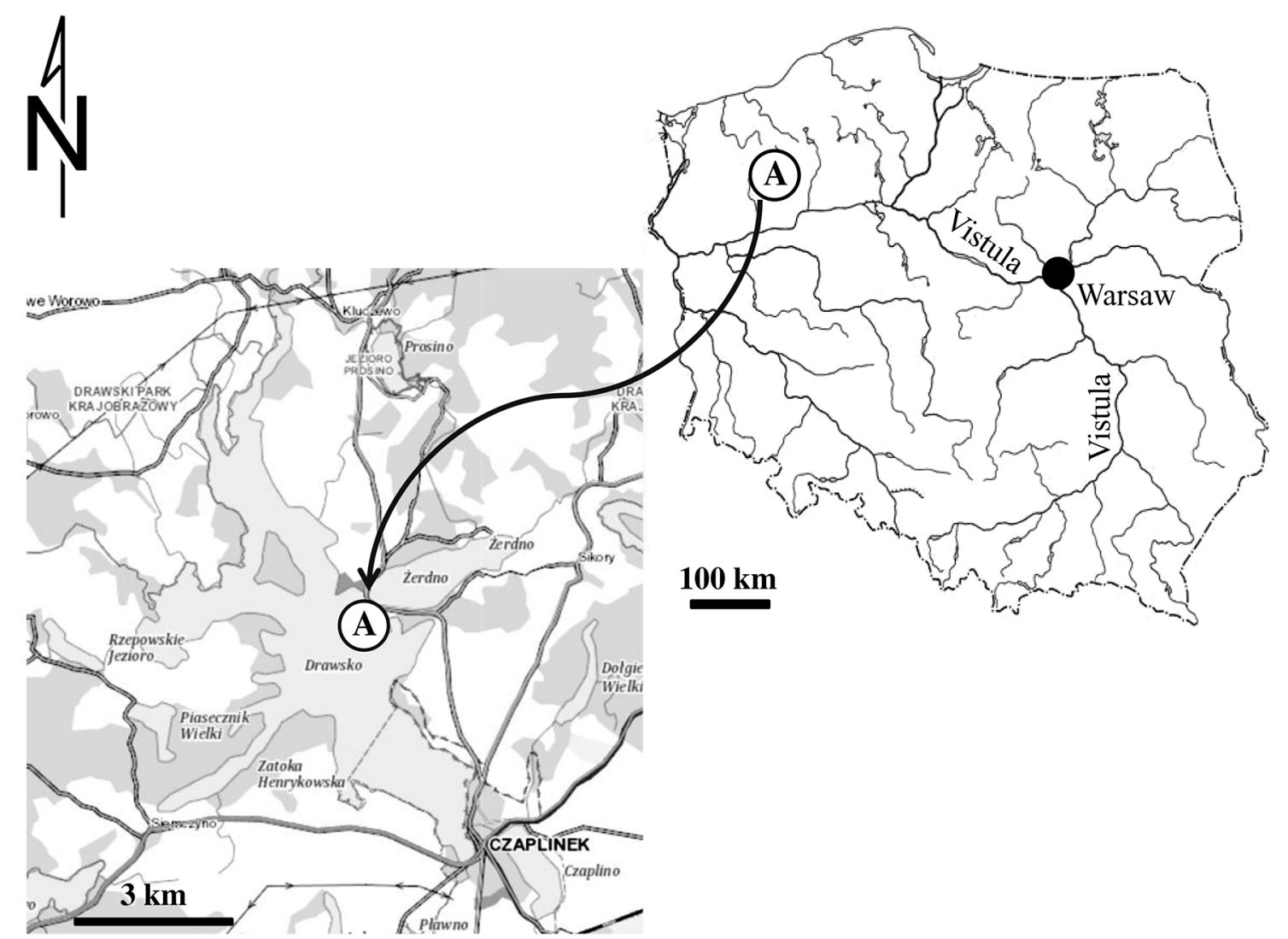

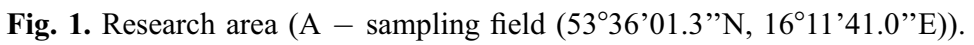

\subsection{Molecular analysis}

Total genomic DNA was isolated with Sherlock AX (A\&A Biotechnology, Gdynia, Poland), according to the producer's manual. The whole spacer region including ITS1, 5.8S rRNA and ITS2 was amplified using the two primers, its5Trem (5'-GGAAGTAAAAGTCGTAACAAGG- $\left.3^{\prime}\right)$ and its 4 Trem (5'-TCCTCCGCTTATTGATATGC-3') (Dvořák et al., 2002). A PCR reaction of each sample was performed in a $20 \mu \mathrm{l}$ reaction mixture, consisting of $3 \mu \mathrm{l}$ of template DNA, $0.6 \mu \mathrm{l}$ of each primer, $2 \mu \mathrm{l}$ of $10 \times$ buffer, $13 \mu \mathrm{l}$ of $\mathrm{ddH}_{2} \mathrm{O}, 0.6 \mu \mathrm{l}$ of $20 \mathrm{mM}$ dNTP (ThermoFisher Scientific, USA) and $0.2 \mu \mathrm{l}$ of Taq-Polymerase (ThermoFisher Scientific, USA). PCR conditions consisted of $5 \mathrm{~min}$ initial denaturation at $95^{\circ} \mathrm{C} ; 60 \mathrm{~s}$ denaturation at $95^{\circ} \mathrm{C}$, followed by $45 \mathrm{~s}$ annealing at $50^{\circ} \mathrm{C}$, and $120 \mathrm{~s}$ elongation at $72^{\circ} \mathrm{C}$ for 35 cycles followed by a final elongation step for $10 \mathrm{~min}$ at $72^{\circ} \mathrm{C}$. A $3 \mu \mathrm{l}$ sample of PCR product was run on a $1.5 \%$ agarose gel for $30 \mathrm{~min}$ at $100 \mathrm{~V}$ to check DNA quality. PCR products were cleaned up by using Clean-up (A\&A Biotechnology, Poland) according to the producer's manual. A sequencing reaction was performed in a $10 \mu \mathrm{l}$ reaction mixture, consisting of $2 \mu \mathrm{l}$ of PCR product, $0.15 \mu \mathrm{l}$ of primer, $1 \mu \mathrm{l}$ of sequencing buffer (BrilliantDye Terminator Sequencing Kit, Nimagen, The Netherlands), $5.85 \mu \mathrm{l}$ of $\mathrm{ddH}_{2} \mathrm{O}$ and $1 \mu \mathrm{l}$ of Terminator (BrilliantDye Terminator Sequencing Kit, Nimagen, The Netherlands). The sequencing program consisted of four steps: $1 \mathrm{~min}$ initial denaturation at $96^{\circ} \mathrm{C}$, followed by $10 \mathrm{~s}$ denaturation at $96^{\circ} \mathrm{C}$, $5 \mathrm{~s}$ annealing at $55^{\circ} \mathrm{C}, 4 \mathrm{~min}$ elongation at $60^{\circ} \mathrm{C}$ for 25 cycles.
Sequencing products were cleaned up by using ExTerminator (A\&A Biotechnology, Poland) and sequenced in Genomed S. A. (Warsaw, Poland). Sequences were deposited in GenBank with the following accession numbers: MT776889, and MT785880-MT785882.

In order to visualize phylogenetic relationships between Schistosomatidae species, selected sequences of nine named species, B. polonica (Accession numbers: MK264353, HM001262, HM001255, FJ793898-907, EF094539), T. stagnicolae (Talbot, 1936) (FJ174540-542), T. regenti (KP271015, GU233740, EF094540), T. szidati (Neuhaus, 1952) (MT041668, MT041670, MT041672), T. franki (Müller and Kimmig, 1994) (KY513272-274), T. physellae (Talbot, 1936) (FJ174562-563, FJ174568), Allobilharzia visceralis (Kolářová, Rudolfová, Hampl et Skírnisson, 2006) (EF071990-991, LC158661-662), Anserobilharzia brantae (Farr and Blankemeyer, 1956) (KC839984), Dendritobilharzia pulverulenta (Braun, 1901) (EF071988, AY713962) were downloaded from GenBank (Rudolfová et al., 2005; Brant and Loker, 2009; Jouet et al., 2009; Rizevsky et al., 2011; Christiansen et al., 2016; Soldánová et al., 2017) and together with sequence obtained in this study for Bilharziella sp., were aligned in BioEdit 5.0.0 (Hall, 1999) with ClustalW multiple alignment (Thompson et al., 1994). The sequences that resulted in at least $85 \%$ identity in NCBI BLAST to our Bilharziella sp. sequence were chosen for the analysis (Altschul et al., 1990). The obtained alignment (827 bp length) comprised 38 sequences in total. For phylogenetic analysis a DNA sequence of Cardicola opisthorchis Ogawa, 


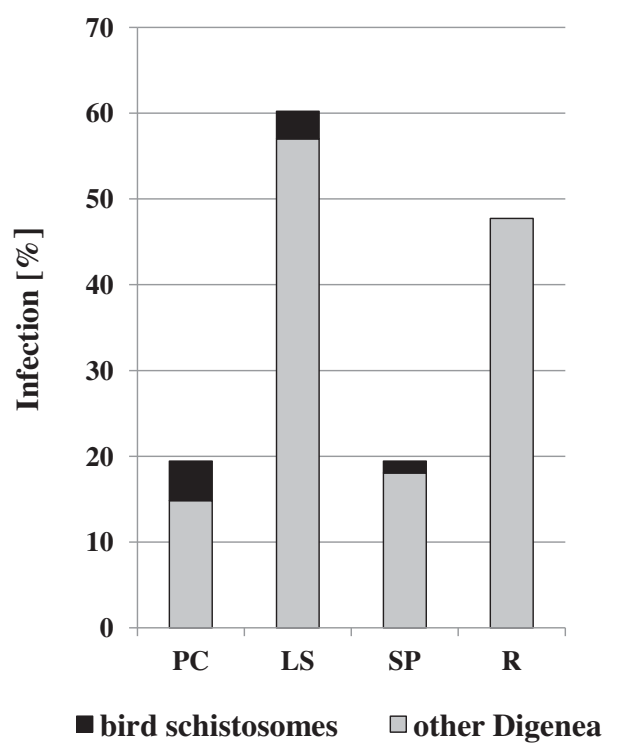

Fig. 2. Digenean invasion of pulmonate snails from Lake Drawsko (PC - Planorbarius corneus, LS - Lymnaea stagnalis, SP Stagnicola palustris, R - Radix sp., Infection [\%] - a proportion of one snail species infected with all Digenea species in relation to all collected snails of this species).

Ishimaru, Shirakashi, Takami et Grabner, 2011 (Trematoda: Aporocotylidae)(KP217052) was used as an outgroup. In order to study intraspecific variability, uncorrected pairwise distances between Bilharziella species were calculated in MEGA7 (Kumar et al., 2016).

Maximum Likelihood (ML) topology was constructed using RAxML v. 8.0.19 (Stamatakis, 2014). The tree branches were supported by bootstrap analysis with 1,000 replicates. Bootstrap support values $\geq 70 \%$ were regarded as significant statistical support. Bayesian inference (BI) marginal posterior probabilities were calculated in MrBayes v. 3.2 (Huelsenbeck and Ronquist, 2001; Huelsenbeck et al., 2001) with 1 cold and 3 heated Markov chains for 10 million generations and trees were sampled every 1000 generations. In the BI consensus tree, clades recovered with posterior probability (PP) between 0.95 and 1.00 were considered well supported, those lower than 0.90 were not shown on the tree. Obtained trees were visualized in FigTree v.1.4.3, available at: http://tree.bio.ed.ac. uk/software/figtree.

\section{Results}

We investigated a total of 317 pulmonate snails: 108 individuals of Planorbarius corneus (Linnaeus, 1758) (Planorbidae), and 93 of Lymnaea stagnalis (Linnaeus, 1758) (Lymneaidae), 72 of Stagnicola palustris (Müller, 1774) (Lymneaidae) and 44 of the genus Radix (Montfort, 1810) (Lymneaidae). Digenean infection was recorded in $35.33 \%$ of all snails examined. Only $2.84 \%$ of these snails were infected with bird schistosomes. Planorbarius corneus were the most common host of bird schistosomes $(4.63 \%)$, followed by L. stagnalis $(3.23 \%)$. Only one individual of $S$. palustris was infected with these parasites (1.3\%), whereas Radix sp. individuals were not infected with bird schistosomes (Fig. 2).
In the presented research, four sequences of bird schistosomes were obtained - only one from P. corneus and three from L. stagnalis. The sequences obtained were blasted by NCBI BLAST (Altschul et al., 1990) to verify species identification and to find similar homologous sequences. The verification in BLAST resulted in fitting to $B$. polonica (cercariae collected in the present study from P. corneus) (EF094539 (Rudolfova, 2006-unpublished); Query cover: 100\%; E-value: 0.00; Perc. ident: 92.67\%) from Anas platyrhynchos Linnaeus, 1758 (Anatinae) as a host, and T. szidati (Neuhaus, 1952) (cercariae collected in the present study from L. stagnalis) (MT041670 (Korycinska, 2020 unpublished); Query cover: 100\%; E-value: 0.00; Perc. ident: 99.79\%) from L. stagnalis as a host.

Maximum Likelihood (ML) and Bayesian (BI) phylogenetic tree resulted in similar tree topology (Fig. 3). Bilharziella sp. examined in this study constituted a sister taxon in relation to other sequences of $B$. polonica. Nevertheless, all sequences of Bilharziella clustered in one strongly supported clade supporting our identification of studied species as a member of this genus. In our analysis Bilharziella clade is the most closely related to D. pulverulenta (Fig. 3).

Genetic distances between Bilharziella sp. and other ITS-2 sequences of $B$. polonica available in GenBank were equal to $5.8 \%$ whereas the intraspecific genetic distance within B. polonica was $0.3 \%$.

DNA isolation from the collected sample of bird schistosome cercariae from $S$. palustris was unsuccessful. Instead, we used morphological features such as furcae presence, pair of pigmented eye spots, 2 pairs of circumacetabular penetration glands, 3 pairs of postacetabular glands, the overall shape and size of the whole body (total length $990(\mathrm{SE} \pm 53) \mu \mathrm{m}$, body length $-340(\mathrm{SE} \pm 21) \mu \mathrm{m}$, tail stem length $-394(\mathrm{SE} \pm 17) \mu \mathrm{m}$, furca length $-256(\mathrm{SE} \pm 22) \mu \mathrm{m}$; measurements based on 5 live cercariae). Based on the morphological features the bird schistosome was identified as Trichobilharzia sp.

\section{Discussion}

Planorbarius corneus and L. stagnalis are typical hosts for the genus Bilharziella and Trichobilharzia, respectively (Faltýnková et al., 2007, 2008; Cichy and Żbikowska, 2016; Horák et al., 2015), and this is consistent with our results. The location of Bilharziella sp. on the presented phylogeny (Fig. 3) showed that it is with high probability a different species than $B$. polonica. Nolan and Cribb (2005) reported that the intraspecific range of the ITS in digenean species ranges from 1.2 to $3.2 \%$, which indicate that studied specimens of Bilharziella sp. should not be easily classified as $B$. polonica. Morphological similarity to the later on one hand and considerable genetic divergence between them strongly suggest the presence of a cryptic species which is not surprising phenomenon especially in case of parasites (e.g. Hanelt et al., 2015; Cai et al., 2020; Benda et al., 2021).

Due to the poor quality of the bird schistosome larvae isolated from the body of the $S$. palustris specimen, we were unable to isolate their DNA. However, according to experimental and molecular studies of other scientists, we can assume that it could be T. szidati (Kock, 2001; Semyenova et al., 2015). 
A. Stanicka et al.: Knowl. Manag. Aquat. Ecosyst. 2021, 422, 12

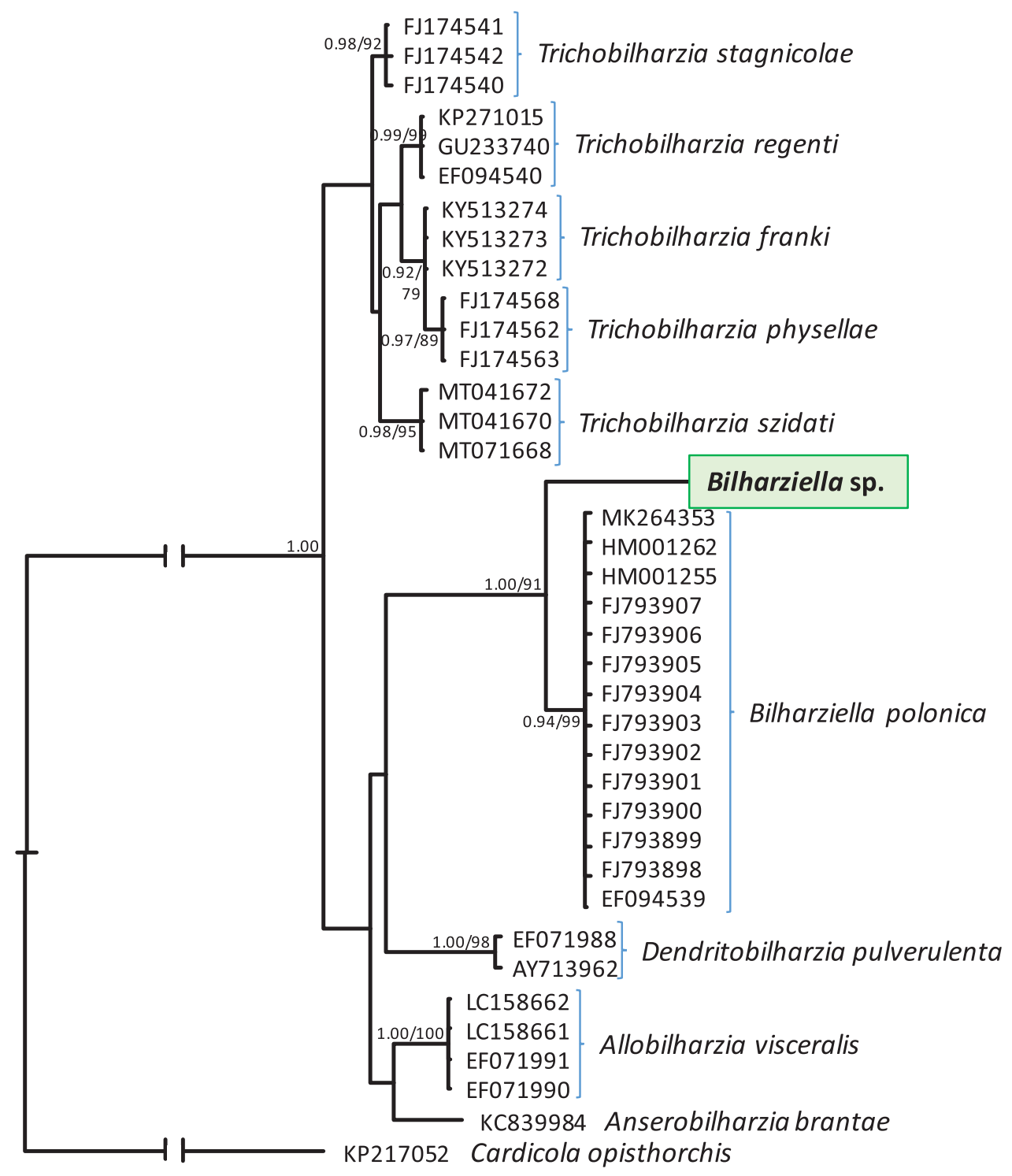

0.2

Fig. 3. A phylogenetic tree of Schistosomatidae species. Only topology of the Bayesian tree is shown. Numbers at nodes indicate Bayesian posterior probability and bootstrap values separated by / mark. Values less than 0.90 for BI and less than 70 for ML are not shown. The scale bar represents 0.2 substitutions per nucleotide position.

In the latest literature, we can find plentiful information about outbreaks of swimmer's itch from lakes where L. stagnalis and/or Radix spp. were infected with bird schistosomes (Żbikowska, 2002, 2004; Ferté et al., 2005; Lawton et al., 2014; Marszewska et al., 2016; Selbach et al., 2016; Caron et al., 2017; Liberato et al., 2019; Tracz et al., 2019; Gulyás et al., 2020). Planorbid snails are rarely investigated for the presence of the genus Bilharziella as a result of an outbreak of swimmer's itch in comparison to Lymnaeidae - hosts of Trichobilharzia spp. (Żbikowska, 2004; Marszewska et al., 2016; Tracz et al., 2019). In our study, the absence of Trichobilharzia sp. in Radix sp. in the results presented is probably associated with the relatively small sample of the tested individuals. Recent reports on outbreaks of swimmer's itch lack information on the presence of bird schistosomes in $S$. palustris specimens (Żbikowska, 2004; Marszewska et al., 2018). For example, in Poland, Cichy and Żbikowska (2016) described the only case of T. szidati larvae in this intermediate host. The less frequent use of S. palustris by bird schistosomes is also confirmed by the fact that in the research presented only one infected individual of this host species was found. The prevalence of bird schistosomes we found in both $L$. stagnalis and P. corneus is comparable to the results of previous studies (Loy and Haas, 2001; Żbikowska, 2004; Faltýnková, 2005; Faltýnková and Haas, 2006; Faltýnková et al., 2007; Soldánová et al., 2010; Marszewska et al., 2016; Marszewska et al., 2018). However, it should be noted that Marszewska et al. (2016) observed 
a lower prevalence of $B$. polonica $(2.9 \%)$ in host snails from the Polish water body, as did Żbikowska (2007), who described the occurrence of $B$. polonica in three out of 29 water bodies where the prevalence of this parasite in $P$. corneus fluctuated from $1 \%$ to $2 \%$. Faltýnková (2005) showed the presence of $B$. polonica in two out of the three lakes in Czechia, where the prevalence of the parasite in P. corneus was $0.2 \%$ and $1.1 \%$. The author indicates a higher prevalence of B. polonica than other bird schistosome species. Dvoř́k et al. (1999), who examined 20 water bodies in Austria, reported the presence of the family Schistosomatidae in intermediate hosts from four of them. B. polonica was recorded there only in one research stand, and its prevalence was $3.8 \%$. Seemingly this result is the most similar to ours, but in absolute numbers, it was only one P. corneus specimen.

The specimens of both snail species - L. stagnalis and $P$. corneus - release rather high numbers of bird schistosome cercariae in comparison to other digenean species (Żbikowska and Marszewska, 2018). However, additionally P. corneus individuals have a significantly longer lifespan than individuals belonging to Lymnaeidae; therefore, these snails can release invasive larvae for extended periods of time (Żbikowska and Marszewska, 2018). According to the authors, the extended survival of infected $P$. corneus is the result of its adaptation in the snail-parasite system. In laboratory conditions, in tests concerning the thermal behaviour of snails, the individuals of $P$. corneus releasing cercariae of $B$. polonica chose significantly lower temperatures than uninfected individuals and L. stagnalis releasing larvae of $T$. szidati. These observations may indicate that the real prevalence of bird schistosome in $P$. corneus in the lake studied was underestimated because in hot weather the snails moved from shallow littoral zones to the deeper zones, where the reduced temperature allowed them to reduce their mortality. Values illustrating the prevalence of the genus Bilharziella in definitive host populations may also be underestimated. Rudolfová et al. (2007) examined 73 birds from Poland, and they detected the presence of bird schistosomes in 21 individuals, of which only one was infected with $B$. polonica. The same authors examined 102 birds from Czechia, among which 23 individuals were infected with bird schistosomes, including 14 birds infected with B. polonica (Rudolfová et al., 2007). The latest research of final hosts presented by Lashaki et al. (2020) indicates that Allobilharzia visceralis and Trichobilharzia spp. had the highest frequency in the world. However, Prüter et al. (2017) suggest that the laborious method of examination of $B$. polonica presence in the CNS (newly discovered location) was the reason why this digenean species has been overlooked in previous studies. Moreover, the high prevalence of B. polonica in Germany demonstrated by these researchers emphasizes the profound importance of this bird schistosome species in the parasite fauna of mallards.

Our finding complements knowledge about the confirmed occurrence of bird schistosomes in European pulmonate snails. Overall, our study reveals the special importance of $P$. corneus as a source of the bird schistosome cercariae. In the literature, we can find single information about the presence of bird schistosome larvae in S. palustris, which was detected in the presented research. This research indicates that the health threat associated with the schistosomatid trematodes need to be further studied by constant monitoring of their occurrence in snail hosts.

\section{Funding}

This project was supported by the grant of the National Science Centre, Poland No. 2017/25/N/NZ8/01345.

\section{Conflicts of interest}

The authors declare no conflict of interest.

\section{Authors' contributions}

AS and EŻ designed the study. AS, ŁM, KZ, AC and DL-C executed the study. AS and $\mathrm{KZ}$ analyzed and interpreted the data and wrote the manuscript. EŻ provided substantive contributions and critical review.

Acknowledgments. We would like to thank Mrs. Hazel Pearson - the native speaker of English - for proofreading of an English version of the manuscript.

\section{References}

Altschul SF, Gish W, Miller W, Myers EW, Lipman DJ. 1990. Basic local alignment search tool. $J$ Mol Biol 215: 403-410.

Benda D, Votýpková K, Nakase Y, Straka J. 2021. Unexpected cryptic species diversity of parasites of the family Xenidae (Strepsiptera) with a constant diversification rate over time. Syst Entomol 46: 252-265.

Bayssade-Dufour C, Martins C, Vuong PN. 2001. Histopathologie pulmonaire d'un modèle mammifère et dermatite cercarienne humaine. Méd Maladies Infect 31: 713-722.

Brant SV, Loker ES. 2009. Molecular systematics of the avian schistosome genus Trichobilharzia (Trematoda: Schistosomatidae) in North America. J Parasitol 95: 941-963.

Cai R, Kayal E, Alves-de-Souza C, Bigeard E, Corre E, Jeanthon C, Marie D, Porcel BM, Siano R, Szymczak J, Wolf M, Guillou L. 2020. Cryptic species in the parasitic Amoebophrya species complex revealed by a polyphasic approach. Sci Rep 10: 2531.

Christiansen AO, Olsen A, Buchmann K, Kania PW, Nejsum P, Vennervald BJ. 2016. Molecular diversity of avian schistosomes in Danish freshwater snails. Parasitol Res 115: 1027-1037.

Caron Y, Cabaraux A, Marechal F, Losson B. 2017. Swimmer's itch in Belgium: first recorded outbreaks, molecular identification of the parasite species and intermediate hosts. Vector Borne Zoonotic Dis 17: 190-194.

Choiński A. 1991. Katalog jazior Polski: Pojezierze Pomorskie. Wydawnictwo Naukowe UAM, Poznan, 221 p.

Cichy A, Żbikowska E. 2016. Atlas of Digenea developmental stages: The morphological characteristics and spread within the populations of freshwater snails from the Brodnickie Lakeland, Poland. Wydawnictwo Naukowe Uniwersytetu Mikołaja Kopernika, Torun, $218 \mathrm{p}$.

Dvořák J, Sattmann H, Horák P, Konecny R. 1999. Bird schistosomes from freshwater snails in Austria, with some notes on current problems (Digenea, Schistosomatidae). Mitt Österr Ges Tropenmed Parasitol 21: 69-76. 
Dvořák J, Vanácová S, Hampl V, Flegr J, Horák P. 2002. Comparison of european Trichobilharzia species based on ITS1 and ITS2 sequences. Parasitology 124: 307-313.

Faltýnková A. 2005. Larval trematodes (Digenea) in molluscs from small water bodies near Šeské Budšjovice, Czech Republic. Acta Parasitol 52: 49-55.

Faltýnková A, Nasincová V, Koblásková L. 2007. Larval trematodes (Digenea) of the great pond snail Lymnaea stagnalis (L.), (Gastropoda, Pulmonata) in central Europe: a survey of species and key to their identification. Parasite 14: 39-51.

Faltýnková A, Nasincová V, Koblásková L. 2008. Larval trematodes (Digenea) of planorbid snails (Gastropoda: Pulmonata) in central Europe: a survey of species and key to their identification. Syst Parasitol 69: 155-178.

Faltýnková A, Haas W. 2006. Larval trematodes in freshwater molluscs from the Elbe to Danube rivers (Southeast Germany): before and today. Parasitol Res 99: 572-582.

Ferté H, Depaquit J, Carré S, Villena I, Léger N. 2005. Presence of Trichobilharzia szidati in Lymnaea stagnalis and T. franki in Radix auricularia in northeastern France: molecular evidence. Parasitol Res 95: 150-154.

Gulyás K, Soldánová M, Orosová M, Oros M. 2020. Confirmation of the presence of zoonotic Trichobilharzia franki following a human cercarial dermatitis outbreak in recreational water in Slovakia. Parasitol Res 119: 531-2537.

Hall TA. 1999. BioEdit: a user-friendly biological sequence alignment editor and analysis program for Windows 95/98/NT. Nucleic Acids Symp Ser 41: 95-98.

Haas W, Pietsch U. 1991. Migration of Trichobilharzia ocellata schistosomula in the duck and in the abnormal murine host. Parasitol Res 77: 642-644.

Hanelt B, Schmidt-Rhaesa A, Bolek MG. 2015. Cryptic species of hairworm parasites revealed by molecular data and crowdsourcing of specimen collections. Mol Phylogenet Evol 82: 211-218.

Horák P, Kolářová L. 2000. Survival of bird schistosomes in mammalian lungs. Int J Parasitol 30: 65-68.

Horák P, Kolářová L. 2001. Bird schistosomes: do they die in mammalian skin? Trends Parasitol 17: 66-69.

Horák P, Mikeš L, Lichtenbergová L, Skála V, Soldánová M, Brant SV. 2015. Avian schistosomes and outbreaks of cercarial dermatitis. Clin Microbiol Rev 28: 165-190.

Huelsenbeck JP, Ronquist F. 2001. MRBAYES: Bayesian inference of phylogeny. Bioinformatics 17: 754-755.

Huelsenbeck JP, Ronquist F, Nielsen R, Bollback JP. 2001. Bayesian inference of phylogeny and its impact on evolutionary biology. Science 294: 2310-2314.

Jouet D, Ferté H, Hologne C, Kaltenbach ML, Depaquit J. 2009. Avian schistosomes in French aquatic birds: a molecular approach. J Helminthol 83: 181-189.

Kock S. 2001. Investigations of intermediate host specificity help to elucidate the taxonomic status of Trichobilharzia ocellata (Digenea: Schistosomatidae). Parasitology 123: 67-70.

Kumar S, Stecher G, Tamura K. 2016. MEGA7: Molecular Evolutionary Genetics Analysis version 7.0 for bigger datasets. Mol Biol Evol 33: 1870-1874.

Lashaki EK, Teshnizi SH, Gholami S, Fakhar M, Brant SV, Dodangeh S. 2020. Global prevalence status of avian schistosomes: A systematic review with meta-analysis. Parasite Epidemiol Control 9: e00142.

Lawton SP, Lim RM, Dukes JP, Cook RT, Walker AJ, Kirk RS. 2014. Identification of a major causative agent of human cercarial dermatitis, Trichobilharzia franki (Müller and Kimmig 1994), in southern England and its evolutionary relationships with other European populations. Parasit Vectors 7: 1-10.
Liberato $\mathrm{C}$ de, Berrilli $\mathrm{F}$, Bossù $\mathrm{T}$, Magliano A, Di Montalbano Filippo M, Di Cave D, Sigismondi M, Cannavacciuolo A, Scaramozzino P. 2019. Outbreak of swimmer's itch in Central Italy: Description, causative agent and preventive measures. Zoonoses Public Health 66: 377-381.

Loy C, Haas W. 2001. Prevalence of cercariae from Lymnaea stagnalis snails in a pond system in Southern Germany. Parasitol Res 87: 878-882.

Marszewska A, Cichy A, Heese T, Żbikowska E. 2016. The real threat of swimmers' itch in anthropogenic recreational water body of the Polish Lowland. Parasitol Res 115: 3049-3056.

Marszewska A, Strzała T, Cichy A, Dąbrowska GB, Żbikowska E. 2018. Agents of swimmer's itch-dangerous minority in the Digenea invasion of Lymnaeidae in water bodies and the first report of Trichobilharzia regenti in Poland. Parasitol Res 117: 3695-3704.

Nolan MJ, Cribb TH. 2005. The use and implications of ribosomal DNA sequencing for the discrimination of digenean species. $A d v$ Parasitol 60: 101-163.

Olivier L. 1953. Observations on the migration of avian schistosomes in mammals previously unexposed to cercariae. J Parasitol 39: 237-246.

Piechocki A, Wawrzyniak-Wydrowska B. 2016. Guide to freshwater and marine mollusca of Poland. Bogucki Wydawnictwo Naukowe, Poznan, $280 \mathrm{p}$.

Prüter H, Sitko J, Krone O. 2017. Having bird schistosomes in mindthe first detection of Bilharziella polonica (Kowalewski 1895) in the bird neural system. Parasitol Res 116: 865-870.

Rizevsky SV, Cherviakovsky EM, Kurchenko VP. 2011. Molecular taxonomic identification of Schistosomatidae from Naroch Lake and Polonevichi Lake in Belarus. Biochem Syst Ecol 39: 14-21.

Rudolfová J, Hampl V, Bayssade-Dufour C, Lockyer AE, Littewood DT, Horák P. 2005. Validity reassessment of Trichobilharzia species using Lymnaea stagnalis as the intermediate host. Parasitol Res 95: 79-89.

Rudolfová J, Littlewood DTJ, Sitko J, Horák P. 2007. Bird schistosomes of wildfowl in the Czech Republic and Poland. Folia Parasitol 54: 88-93.

Soldánová $\mathrm{M}$, Georgieva S, Roháčová J, Knudsen R, Kuhn JA, Henriksen EH, Siwertsson A, Shaw JC, Kuris AM, Amundsen PA, Scholz T, Lafferty KD, Kostiadinova A. 2017. Molecular analyses reveal high species diversity of trematodes in a sub-Arctic lake. Int J Parasitol 47: 327-345.

Selbach C, Soldánová M, Sures B. 2016. Estimating the risk of swimmer's itch in surface waters - a case study from Lake Baldeney, River Ruhr. Int J Hyg Environ Health 219: 693-699.

Semyenova SK, Chrisanfova GG, Guliaev AS, Yesakova AP, Ryskov AP. 2015. Structural and population polymorphism of RT-like sequences in avian schistosomes trichobilharzia szidati (Platyhelminthes: Digenea: Schistosomatidae). Biomed Res Int 2015: 315312.

Soldánová M, Selbach C, Sures B, Kostadinova A, Pérez-Del-Olmo A. 2010. Larval trematode communities in Radix auricularia and Lymnaea stagnalis in a reservoir system of the Ruhr River. Parasit Vectors 3: 56.

Soldánová M, Selbach C, Sures B. 2016. The early worm catches the bird? Productivity and patterns of Trichobilharzia szidati cercarial emission from Lymnaea stagnalis. PLoS One 11: e0149678.

Stamatakis A. 2014. RAxML version 8: a tool for phylogenetic analysis and post-analysis of large phylogenies. Bioinformatics 30 : 1312-1313.

Sulgostowska T, Czaplińska D. 1987. Katalog Fauny Pasożyt-niczej Polski. IV. Pasożyty ptaków. 1. Pierwotniaki i przywry. PWN, Warszawa-Wrocław, 210 p. 
Szidat L. 1930. Über Hautinfektionen bei Bluttrematoden insbesondere bei Bilharziella polonica Kow. Arch f Dermat 160: 304-308. Thompson JD, Higgins DG, Gibson TJ. 1994. CLUSTAL W: Improving the sensitivity of progressive multiple sequence alignment through sequence weighting, position-specific gap penalties and weight matrix choice. Nucleic Acids Res 22: 4673-4680.

Tracz ES, Al-Jubury A, Buchmann K, Bygum A. 2019. Outbreak of Swimmer's Itch in Denmark. Acta Derm Venereol 99: 1116-1120.

Żbikowska E. 2002. Is there a potential danger of swimmer's itch in Poland? Parasitol Res 89: 59-62.
Żbikowska E. 2004. Infection of snails with bird schistosomes and the threat of swimmer's itch in selected Polish lakes. Parasitol Res 92: $30-35$.

Żbikowska E. 2007. Digenea species in chosen populations of freshwater snails in northern and central part of Poland. Wiad Parazytol 53: 301-308.

Żbikowska E, Marszewska A. 2018. Thermal preferences of bird schistosome snail hosts increase the risk of swimmer's itch. J Therm Biol 78: 22-26.

Cite this article as: Stanicka A, Migdalski Ł, Zając KS, Cichy A, Lachowska-Cierlik D, Żbikowska E. 2021. The genus Bilharziella vs. other bird schistosomes in snail hosts from one of the major recreational lakes in Poland. Knowl. Manag. Aquat. Ecosyst., $422,12$. 